\title{
School lunches $v$. packed lunches: a comparison of secondary schools in England following the introduction of compulsory school food standards
}

\author{
Lesley Stevens, Jo Nicholas*, Lesley Wood and Michael Nelson \\ Children's Food Trust, 1 East Parade, Sheffield S1 2ET, UK
}

Submitted 3 July 2012: Final revision received 31 January 2013: Accepted 20 February 2013: First published online 11 April 2013

\begin{abstract}
Objectives: To compare food choices and nutrient intakes of pupils taking a school lunch or a packed lunch in eighty secondary schools in England, following the introduction of the food-based and nutrient-based standards for school food.

Design: Cross-sectional data collected between October 2010 and April 2011. Pupils' lunchtime food choices were recorded over five consecutive days. Setting: Secondary schools, England.

Subjects: A random selection of 5925 pupils having school lunches and 1805 pupils having a packed lunch in a nationally representative sample of eighty secondary schools in England.

Results: The differences in the specific types of food and drink consumed by the two groups of pupils are typical of differences between a hot and cold meal. On average, school lunches as eaten contained significantly more energy, carbohydrate, protein, fibre, vitamin $\mathrm{A}$, folate, Fe and $\mathrm{Zn}$ than packed lunches, and $8 \%$ less $\mathrm{Na}$.

Conclusions: Although neither school lunches nor packed lunches provided the balance of nutrients required to meet the nutrient-based standards (based on about one-third of daily energy and nutrient requirements), school lunches generally had a healthier nutrient profile, with lower $\mathrm{Na}$ and percentage of energy from fat, and higher fibre and micronutrient content. These differences were greater than those reported prior to the introduction of compulsory standards for school lunches. In order to ensure more pupils have a healthy lunch, schools could introduce and enforce a packed lunch policy or make school meals the only option at lunchtime.
\end{abstract}

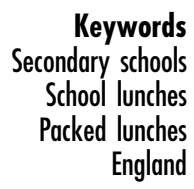

The increases in obesity and its related diseases such as diabetes and hypertension are of international concern. Currently in the UK, $17 \%$ of boys and $15 \%$ of girls aged 2-15 years are reported to be obese (defined as BMI $>$ 95th percentile of the 1990 UK reference population $)^{(1)}$. There is also recent evidence that most of the UK adult population is not meeting general nutrition guidelines like those defined in the 'eatwell plate ${ }^{(2)}$. Data from the most recent National Diet and Nutrition Survey show that on average boys aged 11-18 years eat three portions of fruit and vegetables daily and girls aged 11-18 years eat 2.8 portions, below the recommended five portions. While the percentage of energy obtained from fat is just below the recommended maximum of $35 \%$ for boys and girls (aged 11-18 years), the percentage of energy from SFA is above the recommended $11 \%$ maximum at $12 \cdot 7 \%$ for boys and $12 \cdot 5 \%$ for girls ${ }^{(3)}$.

With food at lunchtime contributing approximately onethird of daily energy and nutrient allowance, school meals or packed lunches can be key to improving children's health. Not only will the choice of food affect health but where improvements have been made to lunchtime food, there is some evidence to suggest this has led to an increase in pupils' concentration during the afternoon session ${ }^{(4,5)}$.

Secondary-school pupils in England have a variety of options for their lunchtime food consumption. They can purchase a lunch, typically from a cash-cafeteria style service (which will offer a two-course set meal, but will also allow pupils to buy freely from a wide choice of items including main meals, starchy foods, fruit and vegetables, sandwiches, drinks and cakes). The other options are bringing in food, either from home or purchased on the way to school from local outlets; going home for lunch (if they live very locally); going off site at lunchtime (if permitted) with the opportunity to purchase food locally; or choosing not to eat at all at lunchtime.

Mandatory food-based and nutrient-based standards have been in place for secondary schools since $2009^{(6,7)}$. 
They have been shown to improve the nutritional quality of the food served and consumed ${ }^{(8)}$. There are no corresponding standards for packed lunches. Some schools may implement and/or enforce a packed lunch policy which, for example, may recommend that confectionery and crisp-like snacks should not be included, in line with the food-based standards. With only $39 \cdot 8 \%$ of secondary pupils taking a school meal at lunchtime in 2011-2012 (9), the majority of pupils will be choosing an alternative option to a school meal and therefore consuming food at lunchtime that does not have to meet any standards. Pupils will choose lunch options consistent with their personal priorities. Packed lunches are often seen by pupils as a way of providing preferred foods at lunchtime, expressing autonomy, or avoiding the need to queue for lunch ${ }^{(10)}$.

Most studies comparing school lunches with packed lunches have been located in primary schools. They consistently show that school lunches have a healthier food and nutrient profile than packed lunches, with noticeably less non-milk extrinsic sugars (NMES), SFA and $\mathrm{Na}^{(11-13)}$. A Canadian study involving pupils aged 10-12 years reported similarly that the nutrient quality of food bought from home was lower than that of food purchased at school, with particular concerns over the very high levels of $\mathrm{Na}$ in food brought from home ${ }^{(14)}$. Two studies comparing school lunches with packed lunches in the UK in the secondary sector have been completed. The first ${ }^{(15)}$, pre-dating the introduction of the school food standards, showed that among 14- and 15-year-olds ( $n$ 757) in Cambridgeshire, protein, starch, carotene and folate, but also SFA and salt, were higher in school lunches than in packed lunches. A more recent study in 136 pupils from eleven secondary schools in four local authorities in England showed that school lunches had higher folate, vitamin $\mathrm{C}$, fibre, $\mathrm{Fe}$ and $\mathrm{Zn}$ content compared with packed lunches ${ }^{(16)}$.

To assess the impact of the introduction of new school food standards, the School Food Trust carried out a survey of a nationally representative sample of eighty secondary schools in England to assess: (i) catering provision of food and drink at lunchtime and morning break; (ii) pupils' choices and consumption of food and drink at lunchtime, including packed lunches and at morning break; (iii) the nutrient content of school lunches and morning break choices; and (iv) compliance of provision with school food standards ${ }^{(8)}$. The present paper explores differences in food choice and nutrient intake between those pupils who took a school lunch and those who consumed a packed lunch.

\section{Methods}

In July 2010 a random sample of 200 secondary schools in England, stratified by region, school stage, school type and postcode, was selected from Edubase ${ }^{(17)}$. Schools included secondary and middle-deemed secondary schools in England. Community, Voluntary-Aided, VoluntaryControlled and Foundation Schools were included in the sample. Schools were excluded (to minimise research burdens) if they had taken part in the previous Secondary School Food Survey ${ }^{(18)}$ or the School Lunch and Behaviour studies in secondary schools ${ }^{(4,5)}$. Schools were approached by letter and asked to take part in the study, with the aim of achieving a representative sample of secondary schools across England. Information sheets were provided for head teachers and catering managers. Data from the previous survey in secondary schools in England in 2004 indicated that eighty schools were sufficient to achieve good generalisability and adequate variation across the selection criteria (school type, region, school size); the aim was to replicate that in the present survey. Of the 200 schools approached, seventy-six schools (38\%) agreed to take part; 105 schools declined, six schools withdrew and thirteen schools did not respond. To achieve a final sample of eighty schools, four schools that had participated in a pilot for the study were approached, of which three agreed to participate, and a further school was recruited via a local authority contact. School reply forms (confirming the school's consent) were collected from participating schools. The final sample included eighty schools spread across all nine government regions, with catering provision that generally matched patterns seen nationally ${ }^{(9)}$. Schools that completed the survey received $\$ 500$.

One week before fieldwork commenced, participating schools were sent information sheets to send to all parents/guardians informing them about the survey and asking them to reply only if they did not wish their child to take part. A list of these students was made available to the fieldworkers on the first day of data collection in each school. Consent from students at the time of data collection was verbal, and non-participation was minimal $(<0.5 \%)$. Fieldworkers received two days' training on sampling and data collection methods, which included recording and weighing food and drink items provided by catering services at lunchtime and recording information about what items pupils chose and ate at lunchtime.

Fieldwork was conducted between October 2010 and April 2011. In each school, on five consecutive days, fieldworkers recorded over the lunchtime period: all food and drink items provided by the catering service; the number of portions and weights of each item provided; and the number of pupils catered for. Missing portion weight data were imputed from similar data within the relevant data sets. Each day, fieldworkers selected fifteen school lunch pupils and five packed lunch pupils (for logistical reasons it was not possible to sample more than five packed lunch pupils). Pupils were selected randomly taking into account the number of serving points and eating areas, and sampling took place across the whole of the lunchtime period to ensure that all year groups 
were represented. Sampling took place after food had been selected for pupils consuming a school meal, using either time (every $n$ minutes) or number (every $n$th pupil) intervals. Packed lunch pupils were sampled either on a 'geographical' basis (a table location and seat number were selected at random each day) or as they entered the eating area (every $n$th pupil). For each pupil, fieldworkers recorded pupil-level information (age, sex and school year), and described all items taken and eaten by school lunch pupils and the weights of all items in the packed lunches. At the end of lunch, all participating pupils returned their tray or lunch box to the fieldworkers, who weighed any leftover items individually. A total of 5969 pupils (2696 boys; 3229 girls; sex not recorded for forty-four) aged 10-19 years had data on school lunch recorded. A further 1823 pupils (741 boys; 1064 girls; sex not recorded for eighteen) aged 11-18 years had data on their packed lunch recorded ${ }^{(19)}$.

Consent to participate was given at the school level, but once approached, pupils were asked if they wished to take part and allowed to opt out of the survey if they so wished.

Weight eaten was estimated by subtracting leftover weight from the portion weight determined for each item taken. Where the value was negative, it was assumed that none of that particular item was consumed. Where pupils did not return their leftover items to be weighed, it was assumed that they had consumed all of their meal.

The energy and nutrient contents of food and drink consumed were estimated using the School Food Trust version of the Food Standards Agency nutrient databank. For reporting purposes, lunch items were categorised into one of twenty-one different food groups. The nutrients assessed were those specified in the nutrient-based standards for school lunches ${ }^{(6,7)}$. Percentage of energy from macronutrients was also calculated. In order to assess dietary variety, the number of food groups that each pupil consumed from was determined. Food groups comprising 'non-permitted items' (as specified by the food-based standards for school lunches ${ }^{(6,7)}$ ) were grouped together for this assessment.

Data were analysed using the statistical software package SPSS version 20. Mean weights of food consumed and energy and nutrient intakes from school lunches and packed lunches were compared using ANCOVA, controlling for age, sex and school. Pupils with missing sex data were excluded from the analysis; results are therefore presented for 5925 school lunch and 1805 packed lunch pupils.

Ethical approval to conduct the study was granted from King's College London Ethical Committee.

\section{Results}

Portion weight data were missing for $4 \cdot 1 \%$ of items from the school lunch data and $2 \cdot 2 \%$ of items from the packed lunch data. The missing data most frequently related to drinks and condiments. In $0.7 \%$ of cases (in the school lunch data) the weight eaten was a negative value and this was spread across a variety of food groups. A number of pupils did not return their leftover items to be weighed; this may have been because there were no leftovers or they simply failed to return their tray $(17 \cdot 3 \%$ of items in the school lunch data and $12 \cdot 8 \%$ of items in the packed lunch data).

Table 1 compares the percentage of pupils who took specific types of food and drink, by food group and by type of lunch (school lunch or packed lunch), and shows the average amount consumed by those taking an item ('consumers'), which includes those who took an item but did not eat it. The differences in the percentage of pupils eating specific types of food and drink are typical of differences between a hot and cold meal. For example, children eating a packed lunch had higher sandwich consumption and lower main dish and starchy food consumption than those eating a school lunch. The weight of the sandwiches consumed as part of a school lunch was much higher than the weight of sandwiches consumed as part of a packed lunch $(155 \cdot 2 \mathrm{~g}$ and $115 \cdot 0 \mathrm{~g}$, respectively). Twice as many pupils took discrete vegetables and salad (excluding baked beans) as part of their school lunch compared with those taking a packed lunch (11.0\% v. $4.7 \%)$, but the amounts consumed were not different $(73.6 \mathrm{~g} \mathrm{v} .67 .4 \mathrm{~g})$. Many more pupils had fruit as part of their packed lunch compared with those taking a school lunch $(36 \cdot 6 \% v \cdot 3 \cdot 1 \%)$, although the average amount of fruit consumed by those having a school lunch was much higher $(114 \cdot 2 \mathrm{~g} v \cdot 78 \cdot 8 \mathrm{~g})$. Notably, $71 \%$ of pupils who took a packed lunch had 'non-permitted foods' (soft drinks, confectionery, savoury snacks) compared with only $9 \cdot 1 \%$ of pupils taking a school lunch (listed as separate items in Table 1). The average amounts consumed in each food group were typically higher among those taking a school lunch than among those taking a packed lunch.

Overall, pupils consuming a packed lunch took food from a similar number of food groups compared with pupils having a school lunch $(2.6$ v. 2.5 food groups; non-permitted food groups were grouped together for this comparison).

Table 2 shows the mean energy and nutrient intakes of pupils eating a school lunch or a packed lunch. Average energy and nutrients consumed from school lunches and packed lunches were below the nutrient-based standards (with the exception of protein and vitamin C). Both types of lunch therefore met the maximum standards for NMES, fat, SFA and $\mathrm{Na}$, and the minimum standards for protein and vitamin $\mathrm{C}$. Neither lunch type met the minimum standards for carbohydrate or the remaining micronutrients. On average, school lunches as eaten contained significantly more energy, carbohydrate, protein, fibre, vitamin $\mathrm{A}$, folate, Fe and $\mathrm{Zn}$ than packed lunches. They also contained 8\% less $\mathrm{Na}(626 \mathrm{mg} v .682 \mathrm{mg}$ ). 
Table 1 Percentage of pupils taking specific items and weight $(\mathrm{g})$ eaten by pupils taking the item ('consumers'), by food group and by lunch type, secondary schools, England, 2011

\begin{tabular}{|c|c|c|c|c|c|c|c|c|}
\hline \multirow[b]{3}{*}{ Food group } & \multicolumn{3}{|c|}{ Pupils taking } & \multicolumn{5}{|c|}{ Weight eaten (g) } \\
\hline & \multirow{2}{*}{$\frac{\text { School lunch }}{\%}$} & \multirow{2}{*}{$\frac{\text { Packed lunch }}{\%}$} & \multirow[b]{2}{*}{$P^{*}$} & \multicolumn{2}{|c|}{ School lunch } & \multicolumn{2}{|c|}{ Packed lunch } & \multirow[b]{2}{*}{$P$} \\
\hline & & & & Mean & SE & Mean & SE & \\
\hline Main dishes & $38 \cdot 1$ & $17 \cdot 1$ & $<0.001$ & $138 \cdot 7$ & $1 \cdot 64$ & $96 \cdot 5$ & $5 \cdot 67$ & $<0.001$ \\
\hline Pizza & $8 \cdot 9$ & $0 \cdot 7$ & $<0.001$ & $113 \cdot 7$ & $1 \cdot 66$ & $118 \cdot 1$ & $19 \cdot 92$ & 0.805 \\
\hline Starchy food not cooked in oil & $26 \cdot 9$ & $0 \cdot 4$ & $<0.001$ & $161 \cdot 7$ & $1 \cdot 84$ & $196 \cdot 4$ & $33 \cdot 14$ & 0.035 \\
\hline Starchy food cooked in oil & $17 \cdot 1$ & 0.5 & $<0.001$ & $117 \cdot 9$ & $1 \cdot 89$ & $42 \cdot 4$ & $7 \cdot 63$ & $<0.001$ \\
\hline Vegetables and salad & $11 \cdot 0$ & $4 \cdot 7$ & $<0.001$ & $73 \cdot 6$ & 1.91 & $67 \cdot 4$ & 4.95 & $0 \cdot 122$ \\
\hline Baked beans & $10 \cdot 0$ & 0.0 & $<0.001$ & $109 \cdot 7$ & $1 \cdot 57$ & - & - & - \\
\hline Sandwichest & $28 \cdot 9$ & $75 \cdot 2$ & $<0.001$ & $155 \cdot 2$ & $1 \cdot 23$ & $115 \cdot 0$ & $1 \cdot 38$ & $<0.001$ \\
\hline Fruitt & $3 \cdot 1$ & $36 \cdot \overline{6}$ & $<0.001$ & $114 \cdot 2$ & $4 \cdot 26$ & $78 \cdot 8$ & $2 \cdot 05$ & $<0.001$ \\
\hline Dairy & $17 \cdot 6$ & $16 \cdot 6$ & $0 \cdot 168$ & $124 \cdot 7$ & $4 \cdot 01$ & $71 \cdot 8$ & $3 \cdot 78$ & $<0.001$ \\
\hline Bread and bread-based items & $7 \cdot 5$ & $3 \cdot 3$ & $<0.001$ & $75 \cdot 8$ & $1 \cdot 87$ & $75 \cdot 0$ & $5 \cdot 23$ & 0.295 \\
\hline Fruit-based desserts & $1 \cdot 6$ & $0 \cdot 0$ & $<0.001$ & $126 \cdot 4$ & $8 \cdot 54$ & - & - & - \\
\hline Other desserts & $30 \cdot 2$ & $13 \cdot 7$ & $<0.001$ & $95 \cdot 0$ & $1 \cdot 48$ & $56 \cdot 6$ & $3 \cdot 18$ & $<0.001$ \\
\hline Permitted snacks and cereals & $0 \cdot 1$ & 0.3 & 0.007 & $39 \cdot 7$ & $10 \cdot 65$ & $31 \cdot 7$ & $8 \cdot 71$ & NA \\
\hline Condiments & $8 \cdot 5$ & $0 \cdot 1$ & $<0.001$ & $40 \cdot 2$ & 1.94 & $16 \cdot 0$ & $4 \cdot 00$ & 0.825 \\
\hline Watert & $5 \cdot 9$ & $15 \cdot 1$ & $<0.001$ & $332 \cdot 4$ & $8 \cdot 30$ & $240 \cdot 0$ & $9 \cdot 39$ & $<0.001$ \\
\hline Fruit juice & $14 \cdot 6$ & $15 \cdot 3$ & 0.234 & $217 \cdot 5$ & $3 \cdot 26$ & $188 \cdot 9$ & $4 \cdot 30$ & $<0.001$ \\
\hline Other drinks incl. soup & $11 \cdot 8$ & $3 \cdot 4$ & $<0.001$ & $261 \cdot 7$ & $4 \cdot 10$ & $147 \cdot 3$ & $14 \cdot 58$ & $<0.001$ \\
\hline \multicolumn{9}{|l|}{ Non-permitted items } \\
\hline Cakes which include confectioneryt & $3 \cdot 6$ & $29 \cdot 2$ & $<0.001$ & $80 \cdot 4$ & $2 \cdot 68$ & $37 \cdot 4$ & $1 \cdot 41$ & $<0.001$ \\
\hline Confectionery & $0 \cdot 3$ & $17 \cdot \overline{2}$ & $<0.001$ & $37 \cdot 5$ & $5 \cdot 21$ & $29 \cdot 9$ & $1 \cdot 28$ & $0 \cdot 104$ \\
\hline Non-permitted snackst & $0 \cdot 6$ & $39 \cdot 1$ & $<0.001$ & $29 \cdot 1$ & $2 \cdot 46$ & $23 \cdot 3$ & 0.39 & 0.001 \\
\hline Non-permitted drinkst & $5 \cdot 0$ & $27 \cdot 4$ & $<0.001$ & 391.5 & 9.05 & $216 \cdot 4$ & $6 \cdot 16$ & $<0.001$ \\
\hline
\end{tabular}

Base (pupils): 5925 school lunches; 1805 packed lunches.

NA means that value cannot be computed due to insufficient data in the cells.

${ }^{*} P$ value based on the $\chi^{2}$ test.

tThe item was consumed by a significantly larger proportion of pupils having packed lunches than by those having school lunches; all other significant differences were in favour of those having school lunches.

Table 2 Mean energy and nutrient intakes (food as eaten), by lunch type, secondary schools, England, 2011

\begin{tabular}{|c|c|c|c|c|c|c|c|}
\hline \multirow[b]{2}{*}{ Nutrient } & \multirow[b]{2}{*}{ Nutrient-based standard } & \multicolumn{2}{|c|}{ School lunch } & \multicolumn{2}{|c|}{ Packed lunch } & \multirow[b]{2}{*}{ Difference } & \multirow[b]{2}{*}{$P$} \\
\hline & & Mean & $\mathrm{SE}$ & Mean & SE & & \\
\hline Energy (kJ) & 2569-2837 & 2083 & 13 & 1879 & 21 & 204 & $<0.001$ \\
\hline Energy (kcal) & $614-678$ & $497 \cdot 8$ & $3 \cdot 14$ & $449 \cdot 1$ & $5 \cdot 02$ & $48 \cdot 7$ & $<0.001$ \\
\hline Protein $(\mathrm{g})$ & $13 \cdot 3$ & $19 \cdot 2$ & 0.14 & $14 \cdot 6$ & $0 \cdot 19$ & $4 \cdot 6$ & $<0.001$ \\
\hline Carbohydrate (g) & $86 \cdot 1$ & $68 \cdot 5$ & 0.45 & $61 \cdot 6$ & 0.72 & $6 \cdot 9$ & $<0.001$ \\
\hline NMES (g) & $18 \cdot 9$ & $14 \cdot 1$ & 0.20 & $14 \cdot 0$ & 0.36 & $0 \cdot 1$ & 0.881 \\
\hline Fat $(g)$ & $25 \cdot 1$ & $18 \cdot 1$ & $0 \cdot 16$ & $17 \cdot 8$ & 0.26 & $0 \cdot 3$ & 0.913 \\
\hline SFA (g) & $7 \cdot 9$ & 6.5 & 0.07 & 6.2 & $0 \cdot 11$ & $0 \cdot 2$ & 0.353 \\
\hline Fibre $(\mathrm{g})$ & $5 \cdot 2$ & $4 \cdot 0$ & 0.04 & $2 \cdot 9$ & 0.05 & $1 \cdot 1$ & $<0.001$ \\
\hline $\mathrm{Na}(\mathrm{mg})$ & 714 & $626 \cdot 2$ & $5 \cdot 24$ & $682 \cdot 0$ & $9 \cdot 11$ & $-55 \cdot 8$ & $<0.001$ \\
\hline Vitamin A $(\mu \mathrm{g})$ & 245 & $174 \cdot 5$ & $3 \cdot 10$ & $126 \cdot 7$ & 4.99 & $47 \cdot 7$ & $<0.001$ \\
\hline Vitamin C (mg) & 14 & $21 \cdot 2$ & 0.35 & $18 \cdot 9$ & 0.73 & $2 \cdot 3$ & 0.062 \\
\hline Folate $(\mu \mathrm{g})$ & 70 & $51 \cdot \overline{5}$ & 0.45 & $39 \cdot 6$ & 0.69 & $11 \cdot 9$ & $<0.001$ \\
\hline $\mathrm{Ca}(\mathrm{mg})$ & 350 & $222 \cdot 4$ & $2 \cdot 34$ & $206 \cdot 7$ & $3 \cdot 37$ & $15 \cdot 7$ & 0.051 \\
\hline $\mathrm{Fe}(\mathrm{mg})$ & $5 \cdot 2$ & $2 \cdot 4$ & 0.02 & $2 \cdot 1$ & 0.03 & $0 \cdot 3$ & $<0.001$ \\
\hline $\mathrm{Zn}(\mathrm{mg}$ & $3 \cdot \overline{3}$ & $2 \cdot 0$ & 0.02 & $1 \cdot 6$ & 0.02 & 0.5 & $<0.001$ \\
\hline \multicolumn{8}{|c|}{ Percentage of energy from: } \\
\hline Protein & $-^{*}$ & $15 \cdot 8$ & 0.09 & $13 \cdot 1$ & $0 \cdot 14$ & $2 \cdot 7$ & $<0.001$ \\
\hline Carbohydrate & $\geq 50$ & $53 \cdot 0$ & $0 \cdot 18$ & $52 \cdot 4$ & $0 \cdot 30$ & $0 \cdot 6$ & 0.272 \\
\hline NMES & $\leq 11$ & $11 \cdot 6$ & 0.20 & $11 \cdot 9$ & $0 \cdot 32$ & -0.3 & $0 \cdot 703$ \\
\hline Fat & $\leq 35$ & $30 \cdot 7$ & $0 \cdot 16$ & $34 \cdot 0$ & 0.27 & $-3 \cdot 3$ & $<0.001$ \\
\hline SFA & $\leq 11$ & $11 \cdot 0$ & 0.08 & $11 \cdot 6$ & $0 \cdot 14$ & -0.6 & 0.001 \\
\hline
\end{tabular}

NMES, non-milk extrinsic sugars.

Base (pupils): 5925 school lunches; 1805 packed lunches.

Difference $=$ school lunch minus packed lunch.

Values shown in bold indicate that minimum standard is met. Values shown in bold italic indicate that maximum standard is met.

${ }^{*}$ No standard for percentage of energy to be met from protein.

The nutrient-based standard for energy assumes that a school lunch will contribute roughly one-third of total daily energy requirements. In practice, the average was about $25 \%$ for a school lunch and about $23 \%$ for a packed lunch. The average school lunch had a better profile of sources of energy than a packed lunch, with 
significantly less energy derived from fat $(30 \cdot 7 \% v$. $34 \cdot 0 \%)$ and SFA $(11 \cdot 0 \% v \cdot 11 \cdot 6 \%)$.

\section{Discussion}

Although neither school lunches nor packed lunches provided the balance of nutrients required to meet the nutrient-based standards (based on about one-third of daily energy and nutrient requirements), school lunches generally had a better nutrient profile, with lower $\mathrm{Na}$ and percentage of energy from fat and SFA, and higher fibre, vitamin A, folate, Fe and $\mathrm{Zn}$ content. This may be because school lunches include more main dishes which are typically higher in meat and a variety of other ingredients, especially vegetables (not reflected in the low percentage of choices for vegetables and salad, but included in composite dishes).

The results presented here are not dissimilar to those reported previously in a small study of secondary school lunches ${ }^{(16)}$. Although the energy content of the lunches (and hence overall nutrient content) was generally higher, the differences in both macro- and micronutrient content were generally in the same direction as reported in the present study. This suggests that school lunches on average have a healthier nutrient profile than packed lunches.

In contrast, the other recent study comparing school and packed lunches in England was conducted before the introduction of compulsory standards ${ }^{(15)}$. Although it was not nationally representative, with many of the pupils coming from families of high socio-economic status, it showed far fewer differences between school and packed lunches, and (for example) higher levels of SFA and $\mathrm{Na}$ in school lunches. As in the present findings, packed lunches contained more confectionery and soft drinks. These findings suggest that the nutritional differences between packed lunches and school lunches have increased since the introduction of the standards, in a direction which generally favours school lunches as the more healthy choice.

There are no statutory regulations for packed lunches. In the present study, packed lunch policies were in place (and enforced) in only a handful of schools, so pupils bringing packed lunches were generally free to eat what they liked. All pupils ate from a similar number of food groups, an indication that dietary variety is similar. However, the food group most commonly consumed by pupils having a packed lunch was sandwiches, which tend to have fewer ingredients than main dishes (more commonly consumed by those taking a school lunch). As a result, it is more difficult to achieve nutrient balance in a packed lunch. Packed lunch pupils were also much more likely to consume food and drink items not permitted under the regulations (e.g. drinks high in sugar and snacks high in fat, sugar and salt). Although these non-permitted items are generally high in fat, sugar and salt, there were no significant differences in NMES or fat intake between the pupils having school lunches or packed lunches, as pupils having a school lunch obtained these nutrients from other items, such as non-fruit based desserts (which include permitted cakes and biscuits) and drinks containing fruit juice. The non-permitted snacks consumed by the pupils eating a packed lunch were also likely to be contributing to the higher $\mathrm{Na}$ intakes. In consequence, the overall balance of intakes from school lunches was closer to both the food-based and nutrientbased standards than intakes from packed lunches.

The low energy content of both types of lunch could be viewed positively as being consistent with the need to reduce obesity and overweight. There is concern, however, that pupils' ability to perform well in the afternoon session at school may be compromised by hunger towards the end of the school day. It is possible that many secondary-school pupils consume a significant part of their lunch at midmorning break and the amount consumed at lunchtime is appropriate in relation to this. Further research is needed to establish what an appropriate lunchtime nutrient intake should be to ensure pupils are able to concentrate during afternoon classes while remaining in energy balance.

The study had some limitations. Details of food eaten by pupils going off site to eat at lunchtime were not collected. Some pupils may have eaten, or purchased, their lunch at mid-morning break, perhaps to be able to attend a club at lunchtime or because they preferred the choice of food at break. Although data were collected on food consumption at morning break, it was not possible to link behaviour at break and lunchtime as different pupils were sampled on each occasion.

The response rate for the survey was $38 \%$. While this is low, the participating schools were spread across all nine geographical regions and had catering provision matching that seen nationally, suggesting that there was no significant selection bias and that the results presented are generalisable to similarly catered English secondary schools.

The present research shows that while secondary school lunches as eaten are not yet at their nutritional optimum, they do provide a better nutrient balance than packed lunches and show an improvement since the introduction of compulsory standards. The ideal would therefore be to encourage more pupils to take a school meal (school lunch take up in secondary schools in 2011-2012 was 39.8\%) and to support schools to continue to improve food and help pupils make better choices, although there will always be some pupils who wish to eat a packed lunch at school. Two options are therefore available to address the nutritional issues relating to packed lunches. One is for schools to develop and enforce packed lunch policies and to provide more information to pupils and parents to encourage better food choices in their packed lunches. The second is to ban packed lunches entirely and to insist (as some schools have opted to do) that all pupils have a school lunch. Price and quality issues may need to be addressed, but this 
provides a straightforward solution that addresses the nutritional divide between school and packed lunches. Of course, this solution is viable only in circumstances where school lunch standards are compulsory and access to less healthy choices and practices is controlled. Preventing pupils from going off site at lunchtime may also help to improve pupils' food and nutrient intakes.

\section{Acknowledgements}

Sources of funding: The study was supported by the School Food Trust. Conflicts of interest: The authors have no conflict of interest. Authors' contribution: M.N. and J.N. designed the study. L.S. and L.W. carried out the data analysis. L.S. prepared the paper. J.N. and M.N. provided editorial support. Acknowledgements: The authors are grateful to the schools and pupils who took part in the study. They would also like to thank the TNS BMRB researchers, nutritionists and interviewers and the School Food Trust researchers.

\section{References}

1. Information Centre for Health and Social Care (2012) Statistics on obesity, physical activity and diet: England 2012. https://catalogue.ic.nhs.uk/publications/public-health/ obesity/obes-phys-acti-diet-eng-2012/obes-phys-acti-diet-eng2012-rep.pdf (accessed January 2013).

2. Harland JI, Buttriss J \& Gibson S (2012) Achieving eatwell plate recommendations: is this a route to improving both sustainability and healthy eating? Nutr Bull 37, 324-343.

3. Bates B, Lennox A, Prentice A et al. (2012) National Diet and Nutrition Survey: Headline Results from Years 1, 2 and 3 (combined) of the Rolling Programme (2008/09-2010/11). http://transparency.dh.gov.uk/2012/07/25/ndns-3-years-report/ (accessed January 2013).

4. Golley R, Baines E, Bassett P et al. (2010) School lunch and learning behaviour in primary schools: an intervention study. Eur J Clin Nutr 64, 1280-1288.

5. Storey HC, Pearce J, Ashfield-Watt PAL et al. (2011) A randomised controlled trial of the effect of school food and dining room modifications on classroom behaviour in secondary school children. Eur J Clin Nutr 65, 32-38.

6. Department of Education and Employment (2007) Statutory Instrument 2007 No. 2359. The Education (Nutritional Standards and Requirements for School Food) (England) Regulations 2007. London: The Stationery Office; available at http://www.opsi.gov.uk/si/si2007/uksi_20072359_en_1

7. Department for Children, Schools and Families (2008) Statutory Instrument 2008 No. 1800. The Education
(Nutritional Standards and Requirements for School Food) (England) (Amendment) Regulations 2008. London: TSO; available at http://www.opsi.gov.uk/si/si2008/uksi_ 20081800_en_1

8. Nicholas J, Wood L \& Nelson M (2012) Secondary School Food Survey 2011: 1. School Lunch: Provision, Selection and Consumption. Sheffield: School Food Trust; available at http://www.childrensfoodtrust.org.uk/research/schoolfood standardsresearch/secondaryschoolfoodsurvey/secondaryschool-food-provision-and-consumption-2011

9. Nelson M, Nicholas J, Wood L et al. (2012) Seventh Annual Survey of Take up of School Lunches in England. Sheffield: School Food Trust; available at http://www.childrens foodtrust.org.uk/research/annual-surveys

10. Ashfield-Watt PAL, Dow B, Abbott $\mathrm{R}$ et al. (2013) Improving adolescent nutrition: a qualitative investigation of influences on the take-up of school food in secondary schools. Public Health Nutr (submitted).

11. Evans CEL, Cleghorn CL, Greenwood DC et al. (2010) A comparison of British school meals and packed lunches from 1990 to 2007: meta-analysis by lunch type. Br J Nutr 104, 474-487.

12. Rogers IS, Ness AR, Hebditch K et al. (2007) Quality of food eaten in English primary schools: school dinners vs packed lunches. Eur J Clin Nutr 61, 856-864.

13. Rees GA, Richards CJ \& Gregory J (2008) Food and nutrient intakes of primary school children: a comparison of school meals and packed lunches. J Hum Nutr Diet 21, 420-427.

14. Taylor JP, Hernandez KJ, Caiger JM et al. (2012) Nutritional quality of children's school lunches: differences according to food source. Public Health Nutr 15, 2259-2265.

15. Prynne CJ, Handford C, Dunn V et al. (2011) The quality of midday meals eaten at school by adolescents; school lunches compared with packed lunches and their contribution to total energy and nutrient intakes. Public Health Nutr (Epublication ahead of print version).

16. Pearce J, Wood L \& Nelson M (2012) Lunchtime food and nutrient intake of secondary school pupils; a comparison of school lunches and packed lunches following the introduction of mandatory food-based standards for school lunch. Public Health Nutr (Epublication ahead of print version).

17. Department for Children, Schools and Families (date not known) EduBase 2. http://www.education.gov.uk/edubase/ home. $x$ tml; jsessionid =5913F21A62A49F53010C3DE60C0 949C5 (accessed July 2010).

18. Nelson M, Bradbury J, Poulter J et al. (2004) School Meals in Secondary Schools in England. Research Report no. 557. London: Department for Education and Skills/ Food Standards Agency; available at https://www.education. gov.uk/publications/standard/publicationDetail/Page1/RR557

19. Nicholas J, Wood L, Harper C et al. (2013) The impact of the food-based and nutrient-based standards on lunchtime food and drink provision and consumption in secondary schools in England. Public Health Nutr (In the Press). 